\title{
Personal-Social Guidance as an Effective Student Emotional Intelligence Development
}

\author{
Mamat Supriatna*, Dina Ervina \\ Guidance and Counseling Department \\ Universitas Pendidikan Indonesia \\ *ma2t.supri@upi.edu,dinaervina9@gmail.com
}

\begin{abstract}
Humans experience emotional development since childhood. Even the ability to react emotionally already exists in infant period with the basic form of emotional behavior is a general stimulation of a strong stimulus. However, as we get older, one's emotional reactions will become less extensive. Emotional intelligence is the ability to regulate life and understand other people's emotions, motivation and socialpersonal abilities. The purpose of this study is to examine personal-social guidance effectiveness in developing students' emotional intelligence. This study used a quantitative approach with a quasi-experimental method. The results showed a significant difference between pretest and Posttest score of emotional intelligence. Thus it can be concluded that personalsocial guidance can develop emotional intelligence effectively. Students who have good emotional abilities can feel, accept, understand and build emotions well They also can motivate themselves and others.
\end{abstract}

Keywords: emotional intelligence, social-personal guidance

\section{INTRODUCTION}

Basically, humans have three types of potential intelligence that must be developed in a balanced way to achieve a success in running their lives. These three types of intelligence are intellectual intelligence, spiritual intelligence, and emotional intelligence. One of the important things in adolescence is achieving emotional independence. But on the other hand adolescence is the most unstable period because adolescents are faced with storms and pressures. Adolescence is a period when emotional tension increases so adolescents experience emotional instability that causes teens to experience uncontrollable emotional experiences Goleman [1] in a report from the National Center for Clinical Infant Program stated that individual success in schools was not predicted based on a collection of facts about self-ability to read, but also by emotional and social measures on him. This is characterized by an ability in which individuals believe in themselves and have interest and know the mindset expected by others. According to the report, almost all individuals with poor school performance do not have one or more elements of emotional skills.

The importance of developing emotional intelligence is a new view that encourages student self-actualization. Seeing from several studies, emotional intelligence has an important role in one's life. Goleman [1] reveals that intellectual intelligence (IQ) only contributes as high as $20 \%$ to one's life success, the remaining $80 \%$ is filled with emotional intelligence. So to be a successful person must have emotional intelligence, not just rely on intellectual intelligence

The fact that humans often act on emotional language rather than logical language increases our awareness of the importance of using emotional language to improve ourselves and others. The phenomena that occur in the field are still many students among adolescents who are still low in emotional intelligence. Based on research conducted by Sumarlin [2] of 304 students in Lohia 1 Public High School $44.40 \%$ still had low or bad emotional intelligence. This is motivated by immature emotions that lead to unstable emotional reactions, always changing from one emotion or mood to another. To achieve emotional maturity, teens must learn to get a picture of a situation that can cause emotional reactions.

There are still many students in SMPN 12 Bandung, as a subject of this research, which is classified as low or has emotional intelligence problems. Based on the results of interviews with BK (guidance and counseling) coordinator and BK class teacher, it was revealed that some students still have low emotional intelligence. Students from SMPN 12 Bandung are selected students with high IQ since the school has high competitive rate. The urge to be the best in academics makes students only prioritize the academic valuesand focus on themselves. They tend to be individualistic and reluctant to think about conditions around them. It caused, a lack of ability to make decisions while problems occur.

Guidance and counseling services are basically aimed at achieving predetermined standards. such as ASCA [3] recommends three areas for learning students in counseling and counseling services in the United States as follows: 1. Academic development, a standard that focuses on the activities of guidance and counseling programs about implementing service strategies to develop students' ability to learn 2. Development career, which is a standard in guidance and counseling programs to help students understand the relationship between school and the world of work, and plan and make successful transitions from school to high school or the world of work and from work to other jobs throughout their lives 3. Social Development / Emotional, namely the standard 
Goleman [6] emotional intelligence is the ability to recognize the feelings of others and our own feelings, and the ability to motivate ourselves and the ability to manage emotions well in themselves and in relationships with others. Emotional intelligence is a side of cognitive intelligence that plays a role in human activity. Emotional intelligence is also a type of social intelligence that involves the ability to monitor emotions of oneself and others, distinguish types of emotions and use them to mobilize their own thoughts and abilities. Salovey and Mayer [7] emotional intelligence is the ability to see, judge, and express emotions effectively. the ability to understand emotions, use feelings to guide cognitive and actions and the ability to regulate emotions of yourself and others. Salovey also provides a basic definition of emotional intelligence in five main areas, namely, the ability to recognize emotions, manage emotions, motivate oneself, recognize the emotions of dressed people, and the ability to build relationships with others.

Cooper and Sawaf [8] say that emotional intelligence is the ability to feel understanding selectively, applying emotional strength and sensitivity as a source of energy and human influence. Emotional intelligence requires ownership of feelings, to learn to recognize, appreciate feelings for oneself and others and respond appropriately, apply them effectively to emotional energy in everyday life both in social life and personal life.

The description above can be concluded that emotional intelligence is the ability of individuals to regulate life in order to understand the feelings of others and feelings of themselves and can motivate and be able to build relationships in personal life and social life.

\section{B. Social-Personal Guidance}

Guidance and Counseling play an important role in developing students 'emotional intelligence, guidance and counseling. They also need to be able to make a guidance and counseling service program to handle students' problems both intellectually, emotionally, spiritually and socially. School guidance and counseling services include personal guidance, social guidance, tutoring and career guidance. There are various guiding meanings expressed by experts. Among them is the idea of guidance put forward by Crow and Crow [9] which states that guidance is assistance provided by someone, male or female, who has an adequate personality and is well trained for each individual of every age to help him organize his own life activities, develop his own outlook on life, make his own decisions and bear his own burdens.

Sukardi [10], social guidance helps students recognize and relate to their social environment based on morality, social responsibility and statehood. Social guidance, which involves: (a) understanding of cultural diversity or customs, (b) social attitudes and (c) the ability to socialize positively with parents, teachers, friends, and other school communities

In general, the purpose of personal-social guidance is to help develop individuals optimally in accordance with their potential and achieve development goals such as personal, 
social, learning and career aspects. According to Yusuf and Nurihsan [11] the purpose of guidance service providers is for individuals to: (a) plan study completion activities, future career and life developments, (b) develop all their potential and strength as optimally as possible, (c) adjust self with the environment of education, society and work, (d) overcome obstacles and difficulties faced, adjustments in the environment

Yusuf and Sugandhi, [12] Social guidance aims to build individuals to achieve the tasks of social development and to be able to solve problems that occur in their lives. The purpose of social guidance is related to the development of social character, that is, students are able to actualize attitudes and behaviors in daily life, in the life of the community and state students can have an attitude of respect for others, empathy, tolerance, and responsibility

The scope of personal-social guidance requires detailed strategies to facilitate the provision of personal-social guidance services. Strategy is basically the structure of service delivery that is carefully planned to achieve the objectives of a program. The social-personal guidance program provides services that are integrated with development programs on personal and social aspects. Personal-social guidance strategies include the objectives of activities, parties involved in activities, material activities and other matters relating to the implementation of personal-social guidance activities

Guez and Allen [13] the problem solving strategies developed have five phases. (1) building a pleasant climate for sharing opinions among other members. (2) express the problem in the discussion (3) the involvement of students in making an assessment of the personal value of the problem discussed. (4) Identify exercises in making alternative actions. (5) involves public commitment to conduct certain behaviors that are finally followed by follow-up behavior. If effective, students are guided to strengthen themselves in taking action in the future

The guidance program contains a number of guidance service activities. A guidance program is a series of planned, organized and coordinated guidance activities over a period of time. The guidance program developed is a clear and clear guideline for supervisors in schools so that guidance activities in schools can be carried out smoothly, effectively, efficiently and can be evaluated both on the program, process and results. According to Suherman [14] a well-organized and mature guidance program will certainly provide many benefits, namely both for participants who get services and for guidance teachers or guidance staff who implement them.

\section{METHOD}

This study used a quantitative approach. According to Sukmadinata [15] a quantitative approach is an approach designed to answer hypotheses accurately using numbers and statistical processing, thus facilitating the process of analysis and interpretation. The quantitative approach is used in the presentation of an overview of the effectiveness of a personalsocial guidance program to develop emotional intelligence. So that this approach can answer the research hypothesis specifically.

To test the success of a personal-social guidance program to develop emotional intelligence, this study used a quasiexperimental method. According to Creswell [16] quasiexperimental research is a research design that has a control group but cannot function fully to control external variables that influence the conduct of experiments. This research aims to examine the effectiveness of social-personal guidance programs that are effective in developing emotional intelligence.

The research design can be described as follows:

\begin{tabular}{|c|c|c|c|}
\hline Group A & $\mathrm{O}_{1}$ & $\mathrm{x}$ & $\mathrm{O}_{2}$ \\
\hline Group B & $\mathrm{O}_{1}$ & - & $\mathrm{O}_{2}$ \\
\hline
\end{tabular}

\section{O1: Pretest}

\section{O2: Posttest}

\section{$\mathrm{X}$ : Guidance Social-Personal Treatment}

The population in this study are all VII grade students at SMPN 12 Bandung. According to Sugiyono, [17] Population is an area consisting of objects that have certain numbers and characteristics set by researchers to be studied and the possibility to draw conclusions. While the sample is part of the number and characteristics possessed by the population.

Sample is collected by using purposive sampling technique, according to Akdon and Ridwan [18] purposive sampling is the technique of determining research subjects used in certain considerations with specific objectives. The selection of subject groups is based on characteristics that have been determined and previously known based on characteristics. Firstly, researcher gave a pretest to all students from VII grade class. It aimed to determine their level of emotional intelligence. Secondly, researcher selected sample in which are students with high, medium and low level of emotional intelligence.

The validity test in the study consisted of instrument feasibility tests, instrument limitations testing, and trial items of instrument items. Instrument reliability is stated operationally as a correlation coefficient (r) [19]. To determine the level of reliability of the instrument, testing was carried out using the Cronbach's Alpha $(\alpha)$ formula. Based on the calculation of the instrument reliability test using SPPS, the alpha value is 0.734 of 45 items. Benchmark alpha reliability coefficient with a value of 0.734 is a high degree of reliability.

\section{RESULTS AND DISCUSSION}

The initial stage in this study was to present a general profile of students' emotional intelligence before participating in the implementation of personal-social guidance activities. This is done to see in general how the profile of students before taking personal-social guidance services. The result revealed that the emotional intelligence of most of the students of SMPN 12 Bandung in the 2018/2019 academic year, are in the 
developing each indicator from the cognitive, affective, and psychomotor aspects.

the knowledge, attitudes, and skills needed related to understanding emotions in the medium category. These were characterized by achievement on cognitive, affective and psychomotor aspects that have not been optimal. It can be seen that students in the high category have percentage at $20 \%$, in the moderate category at $72 \%$, and in the low category at $8 \%$. Student's emotional intelligence percentage of each category from this study are different with Alifah, et al [20] research findings. They have percentage for high category $55 \%$, medium category $38 \%$, and low category $7 \%$.

Based on the data obtained, the average emotional intelligence abilities of students are classified into the medium category. Therefore, various assistance is needed for students to be able to improve their emotional intelligence abilities effectively. In determining the effectiveness of the implementation of personal-social guidance services compared to other guidance the data used is a comparison of the results of the average score of the pretest and posttest of the experimental group and the control group. The findings of the study regarding the effectiveness of the personal social guidance program to develop the emotional intelligence of First Middle School students showed significant results. This effectiveness is known after conducting the Mann Whitney U Test on the data obtained. This test was carried out by using SPSS. The results of testing the effectiveness of each indicator can be seen in table 1.

TABle I. Result of Test of Personal Social Guidance SERVICE EFFECTIVENESS IN DEVELOPING STUDENT EMOTIONAL INTELLIGENCE (PER INDICATOR)

\begin{tabular}{|c|l|l|l|l|}
\hline Aspect & \multicolumn{1}{|c|}{ Indicator } & Sig. & $\boldsymbol{\alpha}$ & \multicolumn{1}{c|}{$\begin{array}{c}\text { explanatio } \\
\text { n }\end{array}$} \\
\hline \multirow{2}{*}{ Cognitive } & $\begin{array}{l}\text { Understanding } \\
\text { Feelings }\end{array}$ & 003 & 0.05 & Sig. \\
\hline & know feelings & 000 & 0.05 & Sig. \\
\cline { 2 - 5 } & Regulate feelings & 001 & 0.05 & Sig. \\
\hline \multirow{4}{*}{ Affective } & Optimistic & 033 & 0.05 & No Sig. \\
\cline { 2 - 5 } & Motivation & 368 & 0.05 & No Sig. \\
\cline { 2 - 5 } $\begin{array}{l}\text { Psikomo- } \\
\text { toric }\end{array}$ & Empathy & 004 & 0.05 & Sig. \\
\cline { 2 - 5 } & Skills in Action & 003 & 0.05 & Sig. \\
\cline { 2 - 5 } & $\begin{array}{l}\text { Puilding } \\
\text { relationships }\end{array}$ & 005 & 0.05 & Sig. \\
\hline
\end{tabular}

Based on the results of the Mann Whitney U Test from the pretest and posttest data there are several indicators that have not increased namely being optimistic and self-motivated (the affective aspect), While the other indicators increase significantly. These indicators are Understanding feelings, recognizing feelings governing feelings, skills in acting, resolving problems, and building relationships

To reinforce the picture of the effectiveness of personalsocial guidance in developing students' emotional intelligence, the table 2 shows the comparison of the average score of the indicators in the experimental class and the control class. Based on the results of the effectiveness test, it can be concluded that in general the personal-social guidance program to develop the emotional intelligence of Middle School students is effective in
TABLE II. EMOTIONAL INTELLIGENCE INDICATOR SCORES IN EXPERIMENTAL AND CONTROL CLASSES

\begin{tabular}{|l|c|c|c|c|}
\hline \multicolumn{1}{|c|}{ Indicator } & \multicolumn{2}{c|}{$\begin{array}{c}\text { Class } \\
\text { Experimental }\end{array}$} & \multicolumn{2}{c|}{ Class Control } \\
\hline & $\begin{array}{c}\text { Pre- } \\
\text { test }\end{array}$ & $\begin{array}{c}\text { Post- } \\
\text { test }\end{array}$ & $\begin{array}{c}\text { Pre- } \\
\text { test }\end{array}$ & $\begin{array}{c}\text { Post- } \\
\text { test }\end{array}$ \\
\hline Understanding Feelings & $57 \%$ & $68 \%$ & $58 \%$ & $62 \%$ \\
\hline know feelings & $59 \%$ & $77 \%$ & $61 \%$ & $59 \%$ \\
\hline Regulate feelings & $58 \%$ & $73 \%$ & $62 \%$ & $65 \%$ \\
\hline Optimistic & $66 \%$ & $74 \%$ & $61 \%$ & $67 \%$ \\
\hline Motivation & $70 \%$ & $75 \%$ & $61 \%$ & $68 \%$ \\
\hline Empathy & $70 \%$ & $74 \%$ & $61 \%$ & $69 \%$ \\
\hline Skills in Action & $70 \%$ & $77 \%$ & $64 \%$ & $63 \%$ \\
\hline Problem Solving & $63 \%$ & $70 \%$ & $66 \%$ & $62 \%$ \\
\hline Building relationships & $53 \%$ & $70 \%$ & $63 \%$ & $60 \%$ \\
\hline
\end{tabular}

The analysis technique used is the Mann Whitney u test non-parametric test. The test results show that the Sig (2 tailed) value of 0.01 . The test results illustrate that there are differences between classes that have been given socialpersonal guidance services with classes that have not been given social-personal guidance services. Based on these results, it was concluded that social personal guidance is effective for developing students' emotional intelligence

Based on the test of the effectiveness of the results of effective personal-social guidance programs to develop students 'emotional intelligence, it means that there are changes in students' behavior before and after being treated in the form of personal-social guidance services. This change in behavior is characterized by an increase in every aspect of emotional intelligence before and after treating a social-personal guidance program.

Guez and Allen [13] personal-social guidance is the process of helping individuals to know how to behave in consideration of others. Personal-social guidance that is done is to help individuals understand themselves, know how to get along with other people, learn ethical manners, take advantage of free time, can be skilled in developing social relations and be responsible.

In the findings of this study although in the end result there are some indicators that are not significantly different as scores. These indicators are on the affective aspect. Affective aspect is the ability of students who are oriented towards attitudes and values that are characterized by being optimistic, motivated, and empathic.

In the affective aspect, optimistic and self-motivated indicators showed ineffective results. An optimistic attitude must be developed in children from an early age as a provision of their lives. Many psychologists in this world believe that optimism can be taught and trained in children. Children can absorb this optimism through the learning process. According to Safaria [21] If a child is trained to implement a variety of optimistic attitude strategies, this attitude will become an optimistic habit. Children who have high optimism have the expected, but there are differences in the pretest and posts test 
following characteristics: 1) still have high morals when facing problems. 2) have good achievements, 3) have high academic achievements, 4) happier and pus in social relationships, 5) recover faster from negative emotions and depression, 6) physically and mentally healthy.

According to Astuty, Sukarti, and Rumiani [22], problems, obstacles, and failures experienced by adolescents will not cause frustration and despair if they have an optimistic attitude towards the problems experienced by the situation. In line with this opinion, Wrosch and Scheier [23], optimistic adolescents, which is focus more on problems in dealing with stress, are more active, planned in dealing with pressing events, and used positive thinking frameworks. Optimism of thought gives support to teenagers for a successful life in every activity.

Along with the explanation of Faisal, Amir and Zulfanah [24] planting and developing an optimistic attitude in children are inseparable from the factors of parents and their environment. Instilling and developing an optimistic attitude can be done by considering the role of thought in children's development, as well as educating children to think positively and teaching children to develop their vision. Developing concepts of unconditional appreciation and acceptance will encourage optimal children development.

In general, pessimistic person tends to blame themselves for their failures. While person who tend to be optimistic will assume that every problem has positive things that can be learned. Unsurprisingly, Optimistic person tend to have better mental and physical health.

As a study conducted by Singh, Shruti and Mishra [25] of 220 adolescents $($ Men $=80$; Women $=140)$ in India, showed that $28.18 \%$ (62 respondents) belong to the very optimistic category, 34, 09\% (75 respondents) are optimistic, $22.27 \%$ (49 respondents) are neutral, and $5.00 \%$ (11 respondents) are pessimistic. Nissa's study [26] of students of SMPN 15 Bandung in the 2014/2015 Academic Year showed that of 92 respondents, $3.26 \%$ were in the pessimistic category, $53.26 \%$ were in the optimistic category, and $4.34 \%$ were in the very optimistic category.

With optimism, individuals will be better in passing through problems in their lives because according to Belsky [27] optimism makes individuals have high energy, working hard to do important things. In line with this opinion, Carver, Scheier, and Segerstrom [28] express an optimist as a person who hopes fully for the possibilities of the future and feels confident in his ability to overcome challenges and reach future goals. Therefore, optimism is important for individuals, including adolescents who are at an important period in their life span.

The self motivation indicator is not effective because it is influenced by several factors. Motivation is anything that becomes a driver of behavior that demands or encourages someone to meet a need and what is used as motivation is a decision that has been determined by the individual as a real need or goal to be achieved. Motivation performs the main function for living things, where it can encourage a person to be more responsible by fulfilling the primary needs that are essential for their survival and existence. According to M.C. Donald [29] motivation is a change in energy of someone that drives or moves him/her to do something to achieve a goal. Arief [30] explained in another opinion, motivation is an internal organism both human and animal that encourages to do something.

Emotional intelligence has an influence on the psychological condition of students during learning activities. Psychological conditions of these students affect the conditions of learning including anger, pleasure, anxiety, irritation, and so forth. As revealed by Agustin [31] that low ability to control emotions is one of the personality characteristics that can cause arrogance. This is in line with some of the previous studies conducted by Platsido [32], Mar [33], Hutasoit [34], Qaisy and Thawabieh [35] which states that of a significant relationship between emotional intelligence both with the boredom syndrome, boredom learning, as well as the level of learning stress in teacher, and students.

Students need to get personal-social guidance services to develop emotional intelligence because at this time students experience rapid development reaching physical, social, and emotional maturity. At this time, it is believed to be a difficult time, both for the teenager himself and for his family and environment. Physical changes experienced by adolescents also cause psychological changes. Hurlock [36] is referred to as a period of heightened emotionality, which is a condition in which emotional conditions appear higher or appear more intense than normal conditions. People who are able to control their emotional intelligence will have a better chance to be successful and be assured to be more calm in solving problems that are classified as complicated from themselves so that they are better at communicating [37]. In line with Permendikbud Number 111 [38] personal-social guidance helps students to interact effectively socially.

The social-personal guidance program compiled based on the policy of the national education department has a pretty good influence in the application of emotional intelligence in the content of social-personal guidance services. Although in the end result there are several indicators that are not significantly different. The indicator is in the affective aspect. On the affective aspect the indicator is optimistic and motivating shows ineffective results. An optimistic attitude must be developed in children from an early age as a provision for their lives. Many psychologists in the world believe that optimism can be taught and trained in children. Children can absorb this optimism through the learning process. According to Safaria [21] If children are trained to implement various optimistic strategies, this attitude will become an optimistic habit. Children who have high optimism have characteristics such as: 1) still have a high fighting spirit when facing problems. 2) have good performance, 3) have high academic achievement, 4) happier and pus in social relations, 5) recover faster than negative emotions and depression, 6) become more physically and mentally healthier.

Providing reinforcement in every treatment (intervention) or activity is very necessary considering students still need to be guided, reminded and strengthened for their behavior so as 
to encourage students to continue to develop their behavior in a positive direction. Moss and Page [39] state that someone who gets positive reinforcement when performing a behavior then he tends to do the behavior again at a later time. Emotional intelligence requires a person to learn to acknowledge, respect the feelings of oneself and others and respond appropriately and effectively using emotional energy in everyday life. The level of emotional intelligence of people becomes better when they are adept at handling emotions, motivating themselves [40] and have high empathy and ability to manage relationships [41].

Changes in student's values are influenced both by the development of emotional intelligence and the methods used when providing personal-social guidance services (intervention). But overall, the personal-social guidance program is effective enough to develop the emotional intelligence of students in class VII of SMPN 12 Bandung in the 2018/2019 Academic Year., Incorporating several methods can improve students' emotional intelligence in content or services. Content is according to student needs. Some methods used are Discussion, Cinema Therapy, and Games. The strengthening activity is enough to influence students' in understanding emotional intelligence.

\section{CONCLUSION}

Based on the results of the effectivity of personal-social guidance to develop student's emotional intelligence, it can be concluded that:

- Personal-social guidance programs are formulated to develop students' emotional intelligence effectively to help develop emotional intelligence. The indicators of emotional intelligence are, recognizing feelings that arise, understanding feelings in acting, regulating feelings, being optimistic, self-motivation, empathy, skills in acting, solving problems and fostering relationships

- There are two indicators that did not increase significantly after being tested using the Man Whitney U Test, namely optimistic and self-motivated indicators. This is influenced by several factors when passing through the intervention.

- Result analysis regarding the effectiveness of social personal guidance in developing emotional intelligence showed a Sig (2 tailed) value of 0.01 . So it can be concluded that the application of personal-social guidance is effective for developing emotional intelligence of junior high school students.

Therefore, the results of this study must be further developed so that each indicator of emotional intelligence increases simultaneously, to enrich the development of theories about personal-social guidance in developing emotional intelligence as part of students' social interaction skills.

\section{REFERENCES}

[1] D. Goleman, Kecerdasan Emosional: Mengapa EI lebih penting daripada IQ. (Translated by Widodo). Jakarta : PT. Gramedia Pustaka Utama, 2009.

[2] Sumarlin, Model Bimbingan Kelompok Berbasis Nilai-Nilai Budaya Muna untuk Meningkatkan Kecerdasan Emosional Siswa (Penelitian pada Siswa SMA Negeri 1 Lohia Kabupaten Muna Sulawesi Tenggara). Tesis. Semarang: Program Pascasarjana Unnes, 2013.

[3] American School Counselor Association, ASCA national model: A framework for school counseling programs. American School Counselor Association, 2012.

[4] S. Yusuf, Bimbingan dan konseling perkembangan. Bandung: Reflika Aditama, 2017.

[5] S. Yusuf, Psikologi Perkembangan Anak dan Remaja. Bandung: Remaja Rosdakarya, 2009.

[6] D. Goleman, Working With Emotional Intelligence. (Terjemahan Alex Tri Kantjono Widodo) Jakarta: PT. Gramedia Pustaka Utama, 2002.

[7] C.R. Snyder and S.J. Lopez, Handbook of Positive Psychology. New York: Oxford University Press, 2002.

[8] E. Fatimah, Psikologi Perkembangan. Bandung: Pustaka Setia, 2006.

[9] Prayitno and E. Amti, Layanan bimbingan dan konseling kelompok. Padang: Jurusan Bimbingan dan Konseling, Fakultas Ilmu Pendidikan, Universitas Negeri Padang, 2004. Unpublished.

[10] D.K. Sukardi, Pengantar Pelaksanaan Program Bimbingan dan Konseling di Sekolah. Jakarta: Rineka Cipta, 2007.

[11] S. Yusuf and J. Nurihsan, Landasan Bimbingan Konseling : PT Remaja Rosdakarya, 2014.

[12] S. Yusuf and N.M. Sugandhi, Perkembangan peserta didik. Jakarta: PT. Raja Grafindo Persada, 2012.

[13] W. Guez and J. Allen, Guidance. Printed in France: UNESCO, 2000.

[14] U. Suherman, Manajeman Bimbingan dan konseling. Bandung : Madani Production, 2009.

[15] N.S. Sukmadinata, Metode Penelitian Pedidikan. Bandung: PT. Remaja Rosdakarya, 2012.

[16] J.W. Creswell, Education Research Planing Constructing and Evaliating quantitative and Qualitative Resarch (third Edition).Upper Saddle River, New Jersey: Person Education, Inc, 2012.

[17] Sugiyono, Statistika Untuk Penelitian. Bandung: Alfabeta, 2016.

[18] Akdon and Ridwan, Aplikasi Statistika dan Metode Penelitian Untuk Administrasi dan Manajemen. Bandung: Dewa Ruci, 2006.

[19] S. Azwar, Reliabilitas dan Validitas. Yogyakarta : Pustaka Pelajar, 2012.

[20] G. Alfiah, H. Opod and J.S.V. Sinolungan, "Gambaran Kecerdasan Emosional Dan Prestasi Belajar Pada Siswa Negeri XI Manado," eBiomedik, vol. 1, no. 1, 2013.

[21] T. Safaria, Spiritual Intelegence (Metode Pengembangan Kecerdasan Spiritual Anak). Yogyakarta: Graha Ilmu, 2007.

[22] Astuty, Sukarti, and Rumiani, Hubungan antara Optimisme dengan Kecenderungan Depresi pada Remaja. Naskah Publikasi Penelitian. Yogyakarta: Universitas Islam Indonesia, 2008.

[23] M.D. Kusumadewi, "Peran stresor harian, optimiesme dan regulasi diri terhadap kualitas hidup individu dengan diabetes melitus tipe 2,” Jurnal Psikologi Islam, vol. 8, no. 1, pp. 47, 2011.

[24] Faisal, Amir and Zulfanah, Membangun Gairah Anak Untuk Berprestasi. Jakarta: PT Alex Media Komputindo, 2011.

[25] Singh, Shruti and Mishra, "Optimism-Pessimism Among Adolescents -A Gender Based Study," International Journal of Science and Research(IJSR), vol. 3, no. 6, pp. 1531, 2014.

[26] A.R. Nissa, "Efektivitas Konseling Model ABCDE Seligman untuk Peningkatan Optimisme Peserta Didik," (Skripsi) Bimbingan dan Konseling, 2015. Unpublished. 
(skripsi). Program Sarjana Keperawatan, Universitas Advent Indonesia, Bandung, 2011. Unpublished.

27] M.N. Ghufron and R. Risnawati, Teori-Teori Psikologi. Yogyakarta: Ar-ruzz Media, 2010.

[28] J. Norrish, J. Robinson and P. Williams, "Positive health. Literature Reviews. Institute Of Positive Education,” Jurnal Psikologi Pendidikan, 2011.

[29] C.L. Fred, "Emotional Intelligence in the Workplace: Application to Leadership," International Journal of Management Bussiness and Administration, vol. 14, no. 1, pp. 1-6, 2011.

[30] S.S. Arief, Media Pendidikan. Jakarta: Raja Grafindo Persada, 2003.

[31] M. Agustin, "Model konseling kognitif perilaku untuk menangani kejanuhan belajar mahasiswa," (Disertasi). Sekolah Pascasarjana, Universitas Pendidikan Indonesia, Bandung, 2009. Unpublished.

[32] M. Platsidio, "The emotional intelligence of greek specil education teacher in relation to burnout and job satisfaction," Journal Schoo Psychology International, vol. 32, no. 1, pp. 60-67, 2010.

[33] S. Mar A, "Hubungan religiusitas dan kecerdasan emosi dengan tingkat kejenuhan belajar pada siswa kelas XI SMA N 11 Yogyakarta," (Tesis). Jurusan Psikologi. Universitas Negeri Yogjakarta, Yogyakarta, 2016. Unpublished.

[34] D.J. Hutasoit, "Hubungan kecerdsaan emosional dengan tingkat stres belajar pada mahasiswa keperawatan Universitas Advent Indonesia,"
[35] L.M. Qaisy and A.M. Thawaibeh, "Assessing stress among university studend," American International Journal Of Contemporary Reseach, vol. 2, no. 2, pp. 110-116, 2012

[36] E.B. Hurlock, Psikologi Perkembangan. (Translated by Soedjarwo) Jakarta: Erlangga, 2000

[37] J.M. George, "Emotions and leadership: the role of emotional intelligence," Human Relations Journals, vol. 53, pp. 1027-1055, 2000.

[38] Perturan Menteri Pendidikan dan Kebudayaan Nomor 111 Tahun 2014 Tentang Bimbingan dan Konseling Pada Pendidikan Dasar dan Pendidikan Menengah. Jakarta: Kementerian Pendidikan dan Kebudayaan.

[39] R.A. Baron and D. Byrne, Psikologi sosial. (Terjemahan Ratna Djuwita) Edisi kesepuluh: jilid 2. Jakarta: Erlangga, 2005.

[40] L. Natalie, J.J. Mary and L.S. Sharon, "The effect of emotional intelligence, age, work, experience, and academic performance," Research in Higher Education Journal, pp. 1-18, 2010. and emotional intelligence: a exploratory study," Leadership and Organizational Development Journal, vol. 21, no. 3, pp. 157-161, 2000.
[41] J. Barling, F. Slater and E.K. Kelloway, "Transformational leadership 